\title{
Impact of Nutritional Health Education on Knowledge and Practices of Mothers of Anemic Children in El Othmanyia Village - Egypt
}

\author{
Ammal M. Metwally ${ }^{1}$, Carine Hanna ${ }^{1 *}$, Yasmine S. Galal ${ }^{2}$, Rehan M. Saleh${ }^{1}$, Nihad A. Ibrahim ${ }^{1}$, Nargis Albert Labib ${ }^{2}$ \\ ${ }^{1}$ Community Medicine Research Department, Medical Research Division, National Research Centre (ID: 60014618), P.O. 12622, \\ Dokki, Giza, Egypt; ${ }^{2}$ Public Health and Community Medicine Department, Faculty of Medicine, Cairo University, Giza, Egypt
}

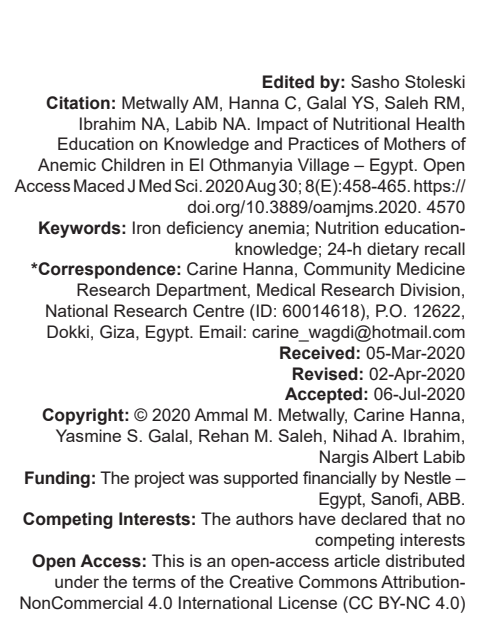

Abstract

BACKGROUND: In Egypt, more than one in four children suffers from some degree of anemia.

AIM: This study was carried out to assess and improve the nutritional knowledge and risky nutritional habits of the mothers of anemic children aged 2-12 years old in El Othmanyia village.

MATERIALS AND METHODS: An interventional study was conducted among anemic children aged 2-12 years old and their mothers in El Othmanyia village, Egypt. The study passed through three stages over 1 and $1 / 2$ years; pre-interventional assessment of awareness $(n=350)$, educational interventions targeting anemic children and their mothers, and post-interventional evaluation of change in awareness and practice.

RESULTS: The mean knowledge \% score of mothers increased significantly after the intervention $(82.2 \pm 14.2 \mathrm{vs.}$ $6.3 \pm 5.8$, respectively). Furthermore, the mean hemoglobin of the studied children increased significantly after the intervention (11. $1 \pm 0.7$ vs. $10.5 \pm 0.7)$. The percent of children with anemia decreased significantly from $100 \%$ to $40.3 \%$ after the intervention $(p<0.001)$

CONCLUSION: The knowledge and practices of mothers are moving in a desirable direction after the health education intervention. Hence, nutrition education is an appropriate, effective, and sustainable approach to combat iron deficiency anemia. Recommendations: A multiple interventional strategies between different ministries to set policies and guidelines that support the healthy nutritional behavior among children are recommended.

\section{Introduction}

Anemia is a global public health problem affecting both developing and developed countries. The most common causes of anemia are nutritional causes as deficiency of one or more of the essential nutrients (usually iron, less frequently folate or Vitamin B12) [1].

It is now recognized that at least half of anemic cases worldwide is due to nutritional iron deficiency with an estimated 120 million suffering from iron deficiency anemia (IDA) [2]. In the Middle East and North Africa region, IDA is considered the most prevalent nutritional disorder among women and children [3]. According to the 2014 Egypt Demographic and Health Survey, more than one in four children in Egypt suffer from some degree of anemia [4]. A study conducted in El Menoufia Governorate showed that $25.6 \%$ of children aged $6-11$ years old have IDA [5]. Another study conducted in El Fayoum Governorate in Upper Egypt showed that $64 \%$ of the children had IDA [6]. IDA continues to be a significant public health problem in Egypt despite the governmental efforts to reduce its prevalence [7]. The current study provides a group of communitybased interventions aiming to improve the awareness and practices of anemic children and their mothers regarding proper nutrition to reduce the prevalence of IDA in Egypt.

\section{Materials and Methods}

\section{Study setting}

The study was conducted in El Othmanyia village - Gharbyia governorate, Egypt.

\section{Study design and participants' characteristics}

A community-based nutrition education interventional study was delivered to mothers of anemic children aged $2-12$ years old along a period of 1 and $1 / 2$ years starting from February 2017 until August 2018. All children aged $2-12$ years old $(n=987)$ in El Othmanyia village were screened for anemia. Confirmatory test was done for the anemic children ( $n=350$ children). Mothers of confirmed mild to moderate anemic children 
aged $2-12$ years old ( $n=104$ mothers) were exposed to the study intervention.

Children with chronic debilitating diseases, other types of anemia as hemolytic anemia, and those with severe anemia (Hemoglobin $(\mathrm{Hb})$ level lower than $7 \mathrm{~g} / \mathrm{dl}$ for children aged 24-59 months and lower than $8 \mathrm{~g} / \mathrm{dl}$ for children aged 5-12 years) were excluded from the study.

\section{Study phases}

The study was done over three phases:

The first phase included: Assessing the awareness, attitude, and behaviors of anemic children and their mothers toward proper diet which was conducted along 3 months starting from February 2017 until April 2017.

The second phase of the study included community-based interventions which were conducted along 1 year from May 2017 until May 2018. Communitybased interventions proved in Egypt to have a profound impact on raising awareness and behavior change for many health settings [8], [9], [10], [11].

The third phase included evaluation of the impact of the interventions on change of the level of beneficiaries' awareness, attitude, and behavior. The evaluation was conducted along a period of 3 months starting from June 2018 until August 2018.

\section{Data collection types and tools during the first and the third phase}

The data-collection tools included laboratory investigations and structured questionnaires.

1. Laboratory investigations: Passes through two levels:

a

Screening all children of El Othmanyia village aged $2-12$ years old (987 children) to detect their hemoglobin level using hemoglobin color scale device $\left(\mathrm{HemoCu} \mathrm{e}^{\mathrm{TM}}\right.$ $\mathrm{Hb} 201 \mathrm{DM}$ ) with accuracy 95\% [12]. Anemic children after being screened for anemia were referred to the primary health care unit for confirmation by complete blood count using the new Medonic M32 analyzer which comes equipped with a high-precision shearvalve [13]. Cutoff levels for hemoglobin were set according to age. Children aged 24-59 months old were considered anemic with $\mathrm{Hb}$ level $<11 \mathrm{~g} / \mathrm{dl}$, while children aged $5-12$ years old were considered anemic with $\mathrm{Hb}$ level $<11.4 \mathrm{~g} / \mathrm{dl}$. Anemia was further classified to mild, moderate, and severe with $\mathrm{Hb}$ cutoff values for children aged 24-59 months were: Mild 10-10.9 g/dl, moderate 7-9.9 g/ $\mathrm{dl}$, and severe lower than $7 \mathrm{~g} / \mathrm{dl}$. While $\mathrm{Hb}$ cutoff for children aged $5-12$ years is mild
11-11.4 g/dl, moderate 8-10.9 $\mathrm{g} / \mathrm{dl}$, and severe lower than $8 \mathrm{~g} / \mathrm{dl}$. All confirmed mild and moderate anemic children aged 2-12 years old were checked for serum iron and ferritin levels at the National Research Centre (NRC) laboratory. Serum Iron was measured on Olympus AU400 automated chemistry analyzer, using fortress diagnostics kit and serum ferritin was measured using an ELISA kit supplied from BLOCHECK, INC (323 vintage park Dr. Foster City. CA 94404)

b. Blood hemoglobin was measured again after the intervention to assess the hemoglobin level of the studied group.

\section{Questionnaires}

\section{Assessment questionnaire}

A well-structured questionnaire was developed after reviewing the literature. Content validity was established by a review committee consisting of three dieticians, three pediatricians, and seven public health specialists from the NRC with extensive experience in this field. The medical history and assessment of knowledge sections were then translated in Arabic by consortium from the NRC team to ensure validity and keeping the original meanings of the end point of the questions. It consisted of three sections of close ended questions filled by the researcher. The information collected identified the following: sociodemographic data, medical history of the affected child, and assessment of knowledge regarding anemia.

\section{Food frequency questionnaire (FFQ)}

The EPIC-Norfolk FFQ that is adapted to the Egyptian culture was used. In addition, it was modified by consortium from the NRC team according to the availability of the food items in the local village market [14].

\section{4-h dietary recall questionnaire}

Mothers were asked to mention all foods and beverages consumed by their children in the past $24 \mathrm{~h}$ using the 24-h dietary recall entry sheet by Nelson et al. in 1994 [15].

A pilot study was carried out on ten mothers of children with normal hemoglobin $(10 \%$ of the study sample) to test the clarity of all questionnaires, estimate the time needed to fulfill each one, as well as to identify any obstacles or problems in data collection. These mothers were not included in the study sample. Results of the pilot study were satisfactory for the knowledge assessment questionnaire and FFQ; however, the 24-h dietary recall was modified and adapted to the Egyptian food habits and the results from the market assessment using NutriSurvey program [16] which contains an extensive collection of food databases from all over the world including Egypt. 
Food items were quantified using the standardization of cups to have the specificity of the amount.

\section{intervention \\ Description of the community-based}

Educational and promotional materials were developed keeping in view the users and the respondents in the community. All the developed and produced materials were distributed to the participants. The developed materials included posters, handouts, food models, and colored food cards. A colorful sheet was created to explain in simple words why it is important for young children to get enough iron in their diet, discussed symptoms of iron deficiency, and provided examples of foods that are good sources of iron, and ways to improve absorption of iron from foods. In addition, the sheet provided a sample menu with high iron meal and snack ideas.

These materials were delivered to the participants in an educational sessions aiming at providing basic knowledge regards IDA. The content of the sessions was based on the review of literature, results of assessment of the pre-interventional phase, as well as the social characteristics of the participants (Table 1).

The participants were divided into small groups (seven groups) based on their geographical location in the village. Each group consisted of fifteen mothers. Each group received seven sessions. Each session lasted approximately $1 \mathrm{~h}$. First, discussion of the session objectives and content was dedicated. The sessions were followed by mothers' participation and interaction for $3 \mathrm{~h}$ using the different activities and teaching aids mentioned before to increase their attention, change their attitude and to enforce them to adopt a healthy nutritional behavior.

A monthly monitoring sheet containing pictures and photos for the types of food was used for follow-up of dietary habits. It was filled daily by the mothers starting from the $1^{\text {st }}$ day after the session for 1 month. Follow-up was done for 4 months.

\section{Ethical disclosures}

The study complied with the revised International Ethical Guidelines for Biomedical Research Involving Human Subjects [17]. The Research and Ethical Committee of NRC approved the study protocol with registration number 16,250. An informed consent was obtained directly from enrolled mothers of children before data collection and after explanation of the study objectives. Confidentiality was provided through the whole phases of the study. In addition, children who were found to be ill during the study were given the appropriate care.

\section{Statistical analysis}

All completed questionnaires were statistically analyzed using SPSS, version 23 (IBM SPSS Statistics for Windows, Version 23.0. Armonk, NY: IBM Corp.).

Data were presented using range, mean, standard deviation, median and interquartile range for quantitative variables, and frequency and percentage for qualitative ones.

Knowledge \% score was calculated as follows: Correct answers were coded by one while the incorrect answers were coded by zero; then, we summated the total achieved score obtained by each subject and divide it by the maximum required score. Knowledge \% score = (total achieved score)/(maximum required score) $\times 100$.

Comparison of each question before and after intervention was performed using McNemar and Wilcoxon tests for binary and ordinal variables, respectively, while other qualitative variables were subjected for Chi-square test. Comparison between quantitative variables before and after intervention was performed using t-test (if data are normally distributed) or Wilcoxon test (if data are not normally distributed). $p<0.05$ were considered statistically significant.

Figures were used to illustrate some information and then exported to access. That information in access was used by NutriSurvey program which is the English translation of commercial German software (EBISpro). Calculation of energy and other macronutrients and

Table 1: Content of educational sessions and various teaching aids used

\begin{tabular}{|c|c|c|}
\hline \multicolumn{2}{|l|}{ Key messages } & \multirow{2}{*}{$\begin{array}{l}\text { Teaching aids } \\
\text { Posters and PowerPoint illustrating definition of anemia and } \\
\text { its symptoms, for example, posters and films showing daily }\end{array}$} \\
\hline $\begin{array}{l}\text { 1. Education about definition of IDA and } \\
\text { its symptoms }\end{array}$ & Fatigue, shortness of breath, hair loss, frequent headaches, brittle nails & \\
\hline 2. Food rich in iron & $\begin{array}{l}\text { Red meat, poultry, seafood, eggs beans, dark green leafy vegetables, such as } \\
\text { spinach, dried fruit, such as raisins and apricots }\end{array}$ & $\begin{array}{l}\text { eating plan for meals and snacks which: Emphasize on diet } \\
\text { with balanced macronutrients and micronutrients diets of food }\end{array}$ \\
\hline \multirow{10}{*}{$\begin{array}{l}\text { Dietary habits that influence iron } \\
\text { absorption (enhancers and inhibitors of } \\
\text { iron absorption) }\end{array}$} & Enhancers of iron absorption include: & rich in iron \\
\hline & $\begin{array}{l}\text { Hem-iron (animal sources of iron) present in meat, poultry, fish, and seafood } \\
\text { Ascorbic acid or Vitamin C present in citrus fruit, their juices, yellow sweet }\end{array}$ & $\begin{array}{l}\text { Give examples of daily meals and snacks as well as number of } \\
\text { serving from each food group/day }\end{array}$ \\
\hline & $\begin{array}{l}\text { potatoes, vegetables such as green leaves, cauliflower, and cabbage } \\
\text { Some fermented or germinated food and condiments, such as soy sauce }\end{array}$ & $\begin{array}{l}\text { Handouts and flyers showing types of foods rich in iron and the } \\
\text { factors that affect iron absorption }\end{array}$ \\
\hline & (note that cooking, fermentation, or germination of food reduces the amount & Colored picture showing example of my healthy plate \\
\hline & of phytates) & Different Food groups cards rich in iron \\
\hline & Inhibitors of iron absorption include: & Puppet show on what causes the child to be anemic and on \\
\hline & Phytates present in cereal bran, cereal grains, highly-extracted flour, legumes, & how to avoid this \\
\hline & nuts, and se & Plastic models of fruits and vegetables to children to play with \\
\hline & Phytic acid impairs the absorption of iron & and to keep \\
\hline & $\begin{array}{l}\text { Iron-binding phenolic compounds (tannins) present in tea, coffee, cocoa, } \\
\text { herbal infusions in general, and some vegetables; calcium, particularly from } \\
\text { milk and milk products }\end{array}$ & $\begin{array}{l}\text { Interactive play time with food cards to identify different food } \\
\text { groups in food pyramid }\end{array}$ \\
\hline 3. Long-term consequences of IDA & language development, cognitive affection, school achievement & \\
\hline
\end{tabular}


micronutrients such as vitamin- $\mathrm{C}$ and iron was done and compared with recommended daily allowance (RDA) reference and difference to mark the deficiency percentage.

\section{Results}

Analysis of the products sold at the shops and markets of the village showed that some iron rich items were not available as red kidney beans, broccoli, whole wheat pasta, quinoa, and oats. Other iron rich items were available but expensive as iron fortified cereals, raisins, prunes, dried apricots, and nuts. However, the market sold other sources rich of iron as eggplant, parsley, beans, spinach, fig, watermelon, in addition to animal protein as beef, chicken, liver, and fish.

Table 2 showed the sociodemographic background of the studied participants, it was found that the mean mothers' age was $32.5 \pm 9$ years. Nearly half of them had secondary education and almost all of them were housewives. Medical history of the studied children was presented in Table 3. About half of the children had suffered previously from anemia. More than half of them were asymptomatic (61.3\%) while only a few complained of pallor (16\%), tiredness (13\%), and lack of concentration (10\%). Only half of the mothers of the anemic children knew they had anemia. Although $71 \%$

Table 2: Sociodemographic characteristics of the studied families

\begin{tabular}{ll}
\hline Sociodemographic data & Description $(\mathrm{n}=104)$ \\
\hline Mother's age (years) & $18-60$ \\
Range & $32.5 \pm 9.3$ \\
Mean \pm SD & $30(25-38)$ \\
Median (IQR) & \\
Mother education $\mathrm{n}(\%)$ & $11(10.6)$ \\
Illiterate & $14(13.4)$ \\
Read and write & $6(5.8)$ \\
Primary & $8(7.7)$ \\
Preparatory & $53(51)$ \\
Secondary & $12(11.5)$ \\
University & \\
Mother occupation $\mathrm{n}(\%)$ & $100(96.1)$ \\
Housewife & $2(1.9)$ \\
Farmer & $1(1)$ \\
Worker & $1(1)$ \\
Professional & \\
Marital status $\mathrm{n}(\%)$ & $100(96.1)$ \\
Married & $3(2.9)$ \\
Widow & $1(1)$ \\
Divorced & \\
Father's education ( $\mathrm{n}=101) \mathrm{n}(\%)$ & $0(0)$ \\
Illiterate & $9(9)$ \\
Read and write & $11(10.9)$ \\
Primary & $12(11.9)$ \\
Preparatory & $57(56.4)$ \\
Secondary & $12(11.8)$ \\
University & \\
Father's occupation ( $\mathrm{n}=101) \mathrm{n}(\%)$ & $27(26.7)$ \\
Not working & $24(23.7)$ \\
Farmer & $42(41.6)$ \\
Worker & $8(8)$ \\
Employee & \\
Number of house tenants & $2-10$ \\
Range & $5.9 \pm 1.7$ \\
Mean $\pm S D$ & $6(5-7)$ \\
Median (IQR) & $1-5$ \\
Number of children in the house & $2.7 \pm 1$ \\
Range & $3(2-3)$ \\
Mean $\pm S D$ & \\
Median (IQR) & \\
\hline & \\
\hline &
\end{tabular}

of children who previously had anemia started treatment, $82 \%$ of them did not follow-up after treatment mostly due to financial issues (50\%). In addition, most of the children did not take any food supplements (93\%) (Table 3).

Regarding the risky dietary habits, an improvement in awareness of the surveyed mothers was noticed after health education as most of the mothers identified drinking tea and having sweets and soda as risky dietary habits. In addition, before the intervention none of mothers knew any of the following risky dietary habits: Drinking milk directly after a meal, mixing molasses with tahini, a diet that is of more plants than animal protein, which improved dramatically after the intervention. Furthermore, after the intervention a significantly higher percent of mothers identified liver and meat, eggplant, leafy vegetables, and molasses as iron rich food $(98 \%, 95.1 \%, 95.2 \%$, and $95.1 \%$, respectively) compared to mothers' knowledge in the pre-intervention assessment $(28.8 \%, 16.3 \%, 13.4 \%$, and $1.9 \%$, respectively). Before the intervention, only few mothers identified defective academic achievement, defective cognition, and language disorders as side effects of anemia $(9.6 \%, 2.8 \%$, and $1.9 \%$, respectively) compared to $88.4 \%, 37.5 \%$, and $61.5 \%$, respectively, after the intervention. These differences were statistically

Table 3: Medical history of anemic children enrolled in the study in El Othmanyia village

\begin{tabular}{|c|c|}
\hline Medical history of the child & $(n=119)$ \\
\hline \multicolumn{2}{|c|}{ Does the child suffer from chronic diseases $\mathrm{n}(\%)$} \\
\hline Yes & $9(7.6)$ \\
\hline No & 109 (91.6) \\
\hline Do not know & $1(0.8)$ \\
\hline \multicolumn{2}{|l|}{ Which chronic disease $\mathrm{n}(\%)$} \\
\hline Bronchial asthma & $3(2.5)$ \\
\hline Constipation & $5(4.2)$ \\
\hline Depression & $1(0.8)$ \\
\hline No chronic disease & $110(92.4)$ \\
\hline \multicolumn{2}{|c|}{ Did he have anemia before $\mathrm{n}(\%)$} \\
\hline Yes & $58(48.7)$ \\
\hline No & $24(20.2)$ \\
\hline Do not know & $37(31.1)$ \\
\hline \multicolumn{2}{|c|}{ Did you know he had anemia $(n=58) n(\%)$} \\
\hline Yes & $31(53.4)$ \\
\hline No & $27(46.6)$ \\
\hline \multicolumn{2}{|l|}{ Was he treated $(n=31) n(\%)$} \\
\hline Yes & $22(71.0)$ \\
\hline No & $9(29.0)$ \\
\hline \multicolumn{2}{|l|}{ For how long $(n=22) n(\%)$} \\
\hline$<6$ months & $21(95.5)$ \\
\hline $6-12$ months & $1(4.5)$ \\
\hline \multicolumn{2}{|c|}{ Did you do follow-up ( $n=22) n(\%)$} \\
\hline Yes & $4(18.2)$ \\
\hline No & $18(81.8)$ \\
\hline \multicolumn{2}{|l|}{ Why not $(n=18) n(\%)$} \\
\hline Financial & $6(50.0)$ \\
\hline TTT incompliance & $10(29.4)$ \\
\hline Ineffective TTT & $2(8.8)$ \\
\hline \multicolumn{2}{|c|}{ Did he suffer from Anal pruritus in the past 2 weeks $n(\%)$} \\
\hline Yes & $23(19.3)$ \\
\hline No & $88(73.9)$ \\
\hline Do not know & $8(6.7)$ \\
\hline \multicolumn{2}{|l|}{ Was he treated $(n=23) n(\%)$} \\
\hline Yes & $22(95.7)$ \\
\hline No & $1(4.3)$ \\
\hline \multicolumn{2}{|c|}{ Is he complaining of the following symptoms $\mathrm{n}(\%)$} \\
\hline Tiredness & $15(12.6)$ \\
\hline Shortness of breath & $4(3.4)$ \\
\hline Pallor & $19(16.0)$ \\
\hline Tachycardia & $1(0.8)$ \\
\hline Tachypnea & $0(0)$ \\
\hline Hypotension & $3(2.5)$ \\
\hline Limbs tingling & $2(1.7)$ \\
\hline Growth retardation & $5(4.2)$ \\
\hline Abnormal eating & $0(0)$ \\
\hline Low food intake & $7(5.9)$ \\
\hline Lack of concentration & $12(10.1)$ \\
\hline Asymptomatic & $73(61.3)$ \\
\hline
\end{tabular}


Table 4: Pre- and post-intervention comparison between mothers' knowledge regarding anemia

\begin{tabular}{|c|c|c|c|}
\hline Parameters studied & Pre $(n=104)$ & Post $(n=104)$ & $p$-value \\
\hline \multicolumn{4}{|l|}{ Definition of anemia $\mathrm{n}(\%)$} \\
\hline Yes & $19(18.3)$ & $97(93.3)$ & \multirow[t]{2}{*}{$<0.001^{\#}$} \\
\hline No & $85(81.7)$ & $7(6.7)$ & \\
\hline \multicolumn{4}{|l|}{ Risky dietary habits $\mathrm{n}(\%)$} \\
\hline Diet mainly of plant origin & $0(0)$ & $65(62.5)$ & $<0.001^{\#}$ \\
\hline Drinking tea directly after a meal & $21(20.2)$ & $94(90.4)$ & $<0.001^{\#}$ \\
\hline Lack of Vitamin C & $9(8.6)$ & 89 (85.5) & $<0.001^{\#}$ \\
\hline Drinking milk directly after a meal & $0(0)$ & $88(84.6)$ & $<0.001^{\#}$ \\
\hline Molasses with tahini & $0(0)$ & 89 (85.5) & $<0.001^{\#}$ \\
\hline Sweets and soda drinks & $17(16.3)$ & $87(83.6)$ & $<0.001^{\#}$ \\
\hline Strict diet & $0(0)$ & $60(57.7)$ & $<0.001^{\#}$ \\
\hline \multicolumn{4}{|l|}{ Iron rich food n (\%) } \\
\hline Leafy vegetables & $14(13.4)$ & $99(95.2)$ & $<0.001^{\#}$ \\
\hline Fruits & $4(3.8)$ & 89 (85.5) & $<0.001^{\#}$ \\
\hline Liver and red meat & $30(28.8)$ & $102(98.0)$ & $<0.001^{\#}$ \\
\hline Molasses & $2(1.9)$ & $99(95.1)$ & $<0.001^{\#}$ \\
\hline Eggplant & $17(16.3)$ & 99 (95.1) & $<0.001^{\#}$ \\
\hline Egg yolk & $5(4.8)$ & $93(89.4)$ & $<0.001^{\#}$ \\
\hline Dried Fruits & $0(0)$ & $95(91.3)$ & $<0.001^{\#}$ \\
\hline \multicolumn{4}{|l|}{ Symptoms and signs of anemia $n(\%)$} \\
\hline Tiredness & $17(16.3)$ & $99(95.1)$ & $<0.001^{\#}$ \\
\hline Shortness of breath & $1(0.9)$ & $89(85.5)$ & $<0.001^{\#}$ \\
\hline Pallor & $10(9.6)$ & $101(97.1)$ & $<0.001^{\#}$ \\
\hline Tachycardia & $0(0)$ & $83(79.8)$ & $<0.001^{\#}$ \\
\hline Tachypnea & $0(0)$ & $78(75.0)$ & $<0.001^{\#}$ \\
\hline Hypotension & $0(0)$ & $92(88.4)$ & $<0.001^{\#}$ \\
\hline Low food intake & $6(5.7)$ & 87 (83.6) & $<0.001^{\#}$ \\
\hline Lack of concentration & $5(4.8)$ & $91(87.5)$ & $<0.001^{\#}$ \\
\hline Limbs tingling & $2(1.9)$ & $70(67.3)$ & $<0.001^{\#}$ \\
\hline Growth retardation & $4(3.8)$ & $92(88.4)$ & $<0.001^{\#}$ \\
\hline Abnormal eating & $0(0)$ & $69(66.3)$ & $<0.001^{\#}$ \\
\hline \multicolumn{4}{|l|}{ Side effects of anemia $\mathrm{n}(\%)$} \\
\hline Defective cognition & $3(2.8)$ & $39(37.5)$ & $<0.001^{\#}$ \\
\hline Defective academic achievement & $10(9.6)$ & $92(88.4)$ & $<0.001^{\#}$ \\
\hline Behavioral changes & $0(0)$ & $72(69.2)$ & $<0.001^{\#}$ \\
\hline Language disorders & $2(1.9)$ & $64(61.5)$ & $<0.001^{\#}$ \\
\hline \multicolumn{4}{|l|}{ Mother knowledge \% score } \\
\hline Range & $0-30$ & $43.3-100$ & $<0.001^{*}$ \\
\hline Mean \pm SD & $6.3 \pm 5.8$ & $82.2 \pm 14.2$ & \\
\hline Median (IQR) & $3.3(3.3-10)$ & $83.3(73.3-93.3)$ & \\
\hline
\end{tabular}

significant with $p<0.001$. Pre- and post-intervention comparison between mothers' knowledge regarding anemia showed that the mean knowledge \% score of mothers increased significantly after the intervention $(82.2 \pm 14.2$ vs. $6.3 \pm 5.8)$ with $p<0.001$ (Table 4).

The prevalence of anemia among the studied children was $35.5 \%$. Moreover, pre-intervention, the hemoglobin screening for all children aged 2-12 years old in El Othmanyia village ranged from $6.8 \mathrm{~g} /$ $\mathrm{dl}$ to $12 \mathrm{~g} / \mathrm{dl}$ while confirmatory hemoglobin ranged from $7.8 \mathrm{~g} / \mathrm{dl}$ to $11.4 \mathrm{~g} / \mathrm{dl}$. Pre- and post-intervention comparison between laboratory results of anemic children showed that the mean hemoglobin of the studied children increased significantly after the intervention (11.1 \pm 0.7 vs. $10.5 \pm 0.7, p<0.001)$ and the percent of children with anemia decreased significantly from $100 \%$ to $40.3 \%$ after the intervention $(p<0.001)$ (Table 5).

Table 5: Pre- and post-intervention comparison between laboratory results of anemic children aged 2-12 years old in EI Othmanyia village

\begin{tabular}{llll}
\hline $\begin{array}{l}\text { Parameters } \\
\text { studied }\end{array}$ & Pre $(\mathrm{n}=119)$ & Post $(\mathrm{n}=119)$ & p-value \\
\hline $\mathrm{Hb}(\mathrm{g} / \mathrm{d})$ & & & \\
$\quad$ Range & $7.8-11.4$ & $8.8-12.7$ & \\
$\quad$ Mean \pm SD & $10.5 \pm 0.7$ & $11.1 \pm 0.7$ & $<0.001^{*}$ \\
$\quad$ Median $(\mathrm{IQR})$ & $10.6(10.3-10.9)$ & $11.1(10.8-11.6)$ & \\
Anemia & & & \\
$\quad$ Yes & $119(100.0)$ & $48(40.3)$ & $<0.001^{\#}$ \\
$\quad$ No & $0(0)$ & $71(59.7)$ & \\
Anemia grade & & $29(24.4)$ & $<0.001^{* *}$ \\
$\quad$ Mild & $74(62.2)$ & $19(16)$ & \\
$\quad$ Moderate & $45(37.8)$ & & \\
\hline
\end{tabular}

Table 6: Percent of children according to their rate of consumption of different food items mentioned by their mothers in El Othmanyia village

\begin{tabular}{|c|c|c|c|c|c|c|c|c|c|}
\hline \multirow[t]{3}{*}{ Items, percent } & \multicolumn{4}{|c|}{ Pre-intervention $(\mathrm{n}=119)$} & \multirow{2}{*}{\multicolumn{4}{|c|}{ Post-intervention $(n=119)$}} & \multirow[t]{3}{*}{$p$-value ${ }^{*}$} \\
\hline & \multicolumn{4}{|c|}{ Frequency } & & & & & \\
\hline & $\begin{array}{l}\text { Did not } \\
\text { eat }\end{array}$ & $\begin{array}{l}\text { Once/ } \\
\text { week }\end{array}$ & $\begin{array}{l}\text { Two/ } \\
\text { week }\end{array}$ & $\begin{array}{l}\text { Three/ } \\
\text { week }\end{array}$ & $\begin{array}{l}\text { Did not } \\
\text { eat }\end{array}$ & $\begin{array}{l}\text { Once/ } \\
\text { week }\end{array}$ & $\begin{array}{l}\text { Two/ } \\
\text { week }\end{array}$ & $\begin{array}{l}\text { Three/ } \\
\text { week }\end{array}$ & \\
\hline Chicken, fish & 31.1 & 60.5 & 8.4 & 0.0 & 7.6 & 50.4 & 42.0 & 0.0 & $<0.001$ \\
\hline Meat, liver & 53.4 & 44.1 & 2.5 & 0.0 & 15.1 & 72.3 & 11.8 & 0.8 & $<0.001$ \\
\hline Eggs & 13.5 & 67.2 & 17.6 & 1.7 & 1.7 & 18.5 & 58.0 & 21.8 & $<0.001$ \\
\hline Beans & 12.6 & 64.7 & 21.8 & 0.9 & 0.8 & 27.8 & 66.4 & 5.0 & $<0.001$ \\
\hline $\begin{array}{l}\text { Fresh } \\
\text { vegetables }\end{array}$ & 43.8 & 44.5 & 10.9 & 0.8 & 10 & 42.9 & 43.7 & 3.4 & $<0.001$ \\
\hline $\begin{array}{l}\text { Cooked } \\
\text { vegetables }\end{array}$ & 16.8 & 56.3 & 26.1 & 0.8 & 2.6 & 24.6 & 66.9 & 5.9 & $<0.001$ \\
\hline Fresh fruits & 53.4 & 37.3 & 9.3 & 0.0 & 15.2 & 36.1 & 44.5 & 4.2 & $<0.001$ \\
\hline Dried fruits & 92.4 & 7.6 & 0.0 & 00 & 31.1 & 50.4 & 18.5 & 0.0 & $<0.001$ \\
\hline Molasses & 61.3 & 37.0 & 1.7 & 0.0 & 12.6 & 23.5 & 59.7 & 4.2 & $<0.001$ \\
\hline Seed & 84.9 & 10.9 & 3.4 & 0.8 & 29.4 & 31.1 & 37.8 & 1.7 & $<0.001$ \\
\hline Pasta/rice & 0.0 & 40.9 & 35.3 & 23.8 & 3.4 & 58.0 & 37.8 & 0.8 & 0.084 \\
\hline Baladi bread & 15.1 & 47.1 & 35.3 & 2.5 & 0.9 & 27.7 & 66.4 & 5.0 & $<0.001$ \\
\hline Cheese & 43.8 & 48.7 & 6.7 & 0.8 & 15.1 & 28.6 & 52.9 & 3.4 & $<0.001$ \\
\hline Yoghurt & 73.1 & 25.2 & 1.7 & 0.0 & 13.5 & 24.4 & 57.1 & 5.0 & $<0.001$ \\
\hline Milk & 24.4 & 64.7 & 9.2 & 1.7 & 4.2 & 23.5 & 52.1 & 20.2 & $<0.001$ \\
\hline $\begin{array}{l}\text { Carbonated } \\
\text { drink }\end{array}$ & 16.8 & 47.9 & 31.9 & 3.4 & 61.4 & 29.4 & 9.2 & 0.0 & $<0.001$ \\
\hline Tea & 14.3 & 37.0 & 42.0 & 6.7 & 53.9 & 31.9 & 13.4 & 0.8 & $<0.001$ \\
\hline Fruit & 15.2 & 71.4 & 13.4 & 0.0 & 3.4 & 16.8 & 69.7 & 10.1 & $<0.001$ \\
\hline Sweet/day & 0.0 & 37.0 & 46.2 & 16.8 & 43.7 & 42.9 & 12.6 & 0.8 & $<0.001$ \\
\hline
\end{tabular}

Table 6 represented the analysis of the rate of consumption of different food items by the surveyed children as mentioned by their mothers, it revealed that the percent of children who consumed chicken, meat, egg, beans, fresh vegetables, cooked vegetables, fresh fruits, and fruit juice (twice/week) increased post-intervention than pre-intervention $(42 \%$ vs. $8.4 \%$, $11.8 \%$ vs. $2.5 \%, 58 \%$ vs. $17.6 \%, 66.4 \%$ vs. $21.8 \%$, $43.7 \%$ vs. $10.9 \%, 66.9 \%$ vs. $26.1 \%, 44.5 \%$ vs. $9.3 \%$, and $69.7 \%$ vs. $13.4 \%$ ), respectively, and the difference was statistically significant.

Results also showed that the mean daily intake of protein, Vitamin D, calcium, Iron, and zinc increased significantly post-intervention. Despite this increase in the consumption, yet the percent intake in relation to the RDAs and dietary reference intake is still low for Vitamin D $(72.3 \%)$, calcium $(78.6 \%)$, iron $(79.2 \%)$, and zinc $(84.1 \%)$. Furthermore, the percent of children who consumed one cup per serving of drinks

Table 7: Mean $\pm S D$ of the main daily nutrients' intake and the $\%$ of intake in relation to the RDAs and DRIs of study subjects

\begin{tabular}{|c|c|c|c|c|}
\hline Nutrient intake & $\begin{array}{l}\begin{array}{l}\text { Pre-intervention } \\
(\mathrm{n}=119)\end{array} \\
\text { Mean } \pm \mathrm{SD} \\
\% \mathrm{RDA} \text { and } \mathrm{DRI}{ }^{\star \star}\end{array}$ & $\begin{array}{l}\text { Post-intervention } \\
(n=119) \\
\text { Mean } \pm \text { SD } \\
\% R D A \text { and DRIs }\end{array}$ & P value ${ }^{\#}$ & RDAs/DRIs \\
\hline Energy (Cal) & $\begin{array}{l}1885.93 \pm 25.32 \\
104.77\end{array}$ & $\begin{array}{l}1701.76 \pm 28.51 \\
94.54\end{array}$ & $<0.001^{*}$ & 1800 \\
\hline Protein (g) & $\begin{array}{l}27.53 \pm 3.03 \\
91.77\end{array}$ & $\begin{array}{l}32.49 \pm 3.12 \\
108.30\end{array}$ & $<0.001^{*}$ & 30 \\
\hline Fat (g) & $\begin{array}{l}81.29 \pm 3.98 \\
135.48\end{array}$ & $\begin{array}{l}61.87 \pm 4.94 \\
103.12\end{array}$ & $<0.001^{*}$ & 60 \\
\hline Carbohydrate (g) & $\begin{array}{l}289.57 \pm 43.80 \\
222.75\end{array}$ & $\begin{array}{l}253.74 \pm 38.51 \\
195.191\end{array}$ & $<0.001^{*}$ & 130 \\
\hline Dietary fiber (g) & $\begin{array}{l}16.91 \pm 4.35 \\
67.64\end{array}$ & $\begin{array}{l}23.17 \pm 9.05 \\
92.68\end{array}$ & $<0.001^{*}$ & 25 \\
\hline Vitamin $\mathrm{A}(\mu \mathrm{g})$ & $\begin{array}{l}437.19 \pm 15.34 \\
62.46\end{array}$ & $\begin{array}{l}709.25 \pm 13.28 \\
101.32\end{array}$ & $<0.001^{*}$ & 700 \\
\hline Vitamin D $(\mu \mathrm{g})$ & $\begin{array}{l}4.48 \pm 0.47 \\
44.80 \% \%\end{array}$ & $\begin{array}{l}7.23 \pm 0.52 \\
72.30\end{array}$ & $<0.001^{*}$ & 10 \\
\hline Calcium (mg) & $\begin{array}{l}643.51 \pm 37.21 \\
64.35\end{array}$ & $\begin{array}{l}786.17 \pm 49.31 \\
78.62\end{array}$ & $<0.001^{*}$ & 1000 \\
\hline Iron (mg) & $\begin{array}{l}4.19 \pm 0.38 \\
41.90\end{array}$ & $\begin{array}{l}7.92 \pm 0.80 \\
79.20\end{array}$ & $<0.001^{*}$ & 10 \\
\hline Zinc (mg) & $\begin{array}{l}6.28 \pm 2.15 \\
62.80\end{array}$ & $\begin{array}{l}8.41 \pm 2.70 \\
84.10\end{array}$ & $<0.001^{*}$ & 10 \\
\hline
\end{tabular}


as carbonated drinks ( $44 \%$ vs. $37 \%$ ) and tea ( $44 \%$ vs. $27 \%$ ) decreased post-intervention while the percent of children who consumed three pieces or more of sweets daily decreased post-intervention (11\%) compared to pre-intervention (62\%) (Table 7).

\section{Discussion}

The prevalence of anemia among children aged 2-12 years old in El Othmanyia village, Egypt was $35.5 \%$. This result was higher than the result presented by Abdel-Rasoul et al. in Menoufia, Egypt in 2015 (25.6\%). Other studies in different countries showed higher prevalence of anemia; in Kenya (92\%), Ghaza (59.7\%), and Kazakhstan (49.8\%) [18], [19], [20].

In the current study, the percent of anemic children significantly decreased from $100 \%$ before the intervention to $40 \%$ after the intervention. This comes in accordance with a study in the United States which showed that the prevalence of anemia dropped to $28.6 \%$ in the group who received nutrition education sessions versus $62.5 \%$ in the control group [21]. Moreover, the mean hemoglobin of the studied children increased significantly after the nutritional educational sessions. These results were similar to the results presented by Gitau et al. in Kenya (12.8 g/dl-13.4 g/dl) and Grover and Choudhary in India (8.55 g/dl-10.66 g/dl) [22], [23]. Another study conducted in India in 2019 showed that anemia cure rate was higher in children in the intervention group compared with the control group (55.7\% vs. $41.4 \%$ ) [24]. However, a study in Iran showed no significant increase in mean hemoglobin level after the nutritional educational intervention [25].

This study highlights marked gaps in nutrition related knowledge of mothers in El Othmanyia village. Before the intervention the mean knowledge score of mothers was 6.3 and it increased significantly after the intervention (82.2). These results come in agreement with the results presented by Kumari and Dubey in Rajasthan (9.3 vs. 13.83) [26]. Other studies also showed comparable results in Kenya (9.87 vs. 39.29), Selangor and Kuala Lumpur (48.3 vs. 55$)$, and Ghana (8.3 vs. 21.6) [27], [28], [29].

Before the intervention mothers had defective knowledge concerning IDA which significantly improved after the intervention. Regarding the definition of anemia, our study showed that the percent of mothers aware of the definition of anemia significantly increased after the intervention. This comes in agreement with AbdelRasoul et al. in Egypt in 2017 (93\% vs. 55\%) [30]. Further assessment of the knowledge revealed that before the intervention, few mothers identified drinking tea directly after the meal as a risky dietary habit. However, after the intervention, a significant improvement was detected. A study conducted in India to examine anemia-related knowledge in adolescent schoolgirls also showed that only $13.3 \%$ of participants were able to identify drinking tea post meals as a risk factor for anemia [31].

Regarding other risky dietary habits, few mothers reported lack of Vitamin $\mathrm{C}$ in a meal before the intervention. However, after the intervention, our results showed significant improvement. These results were in agreement with a study carried in Malaysia where $100 \%$ of participants who received the intervention were aware that tea inhibits iron absorption and Vitamin C enhances iron absorption compared to $78.8 \%$ and $78.2 \%$, respectively. However, no improvement was demonstrated by the counterpart group [32]. Another study carried in Egypt showed similar results [30]. It is suggested to start maternal education as early as possible even before conception. Several Egyptian studies showed the influence of early educational programs and early initiation of breast feeding on improving the Egyptian dietary habits to healthy one with subsequent influence on improvement of the cognitive and psychosocial function [33], [34], [35], [36].

In addition, before the intervention, only few mothers identified tiredness, pallor, and delayed child's growth as symptoms of anemia. These results were much lower than those presented by Abdel-Rasoul et al., 2017 in Egypt (38\%, 89\%, and 42\%, respectively) [30]. However, after the intervention comparable results were found where most of the participants identified these as symptoms of anemia.

In addition to defective knowledge in this study, poor eating habits are another reason for the high rates of anemia among children. Their daily iron requirements are not met by the typical diet despite availability of iron rich food in the market. This is because of an inadequate intake of iron-rich foods and foods that enhance iron absorption, and/or excess intake of inhibitors of iron absorption such as tea and whole wheat bread in addition to skipping meals. Many Egyptian studies showed that school meals have profound effect on improving the dietary intake of minerals and vitamins and improving their cognitive functions and academic achievements [37], [38].

Analysis of the FFQ showed that the percent of children who consumed iron rich food (twice/week) as chicken and fish, meat and liver, green leafy vegetables, increased significantly post-intervention. Other studies also reported an increase in consumption of iron rich foods after nutrition intervention [39], [29], [23]. Furthermore, our study showed that the percent of children who consumed carbonated drink, tea, and sweets decreased significantly after the intervention compared to before the intervention. Likewise, Rojhani and Niewiadomska-Bugaj revealed similar results in the United States in 2004 (52\% vs. 46\%) [21].

Analysis of the 24-h dietary recall of participants in this study revealed a significant increase in the mean daily intake of protein, Vitamin A, calcium, Iron, and zinc post-intervention and this comes in concordance with 
a study done in Kenya [27]. Another study conducted in Indonesia among 83 female adolescents aged 16-18 years students of the Hidayatullah Arrohmah Islamic Boarding School Malang showed that before the intervention $66 \%$ of respondents had low protein intake. However, the protein intake increased after the intervention (87\%). As for iron, about $92 \%$ and $2 \%$ respondents were in very low and low intake. However, after the intervention this number decreased to $86 \%$ and $11 \%$, respectively. However, there was no effect of the nutrition education on the Vitamin C intake [40].

There were some limitations through the study, which could not be handled. Dietary habits of the children were more influenced by the culture, family, peers, media, and environment. Moreover, due to the cultural habit that all family members eat from one big dish, it was difficult to estimate the portion size that the children eat. Furthermore, the geographic place of the village being $3 \mathrm{~h}$ away from Cairo with unprepared roads resulted in difficulty in transporting the blood samples from the village to the laboratory of the NRC especially that there was no centrifuge in the village.

\section{Conclusion and Recommendations}

The study showed that the knowledge and practice of most mothers of anemic children have changed dramatically as a result of the applied interventions. This reflects the necessity of educational interventions to the poor rural communities to promote the health of the future generations.

Comprehensive nutritional education can have a great impact on the health of anemic children. However, to reduce the prevalence of IDA in Egypt, an intercollaborative approach between different ministries is recommended to set polices and guidelines that support the healthy nutritional behavior among children. Furthermore, the role of school is fundamental in controlling the problem through managing the food choices at the school.

\section{Acknowledgments}

This study was conducted through a project titled "A community-based nutritional behavioral intervention for healthy kids: Toward an exemplary model village" under the leadership of Prof. Dr. Ammal Mokhtar Metwally (Principal Investigator). The project was supported financially by Nestle - Egypt, Sanofi, ABB. The authors express their deeply appreciation to the Ministry of Social Solidarity, Ministry of Health and population, and the research team of the National
Research Center of Egypt. Special thanks to the volunteers, mothers, children, and the community leaders in the village who participated in this work.

\section{References}

1. Al Ghwass MM, Halawa EF, Sabry SM, Ahmed D. Iron deficiency anemia in an Egyptian pediatric population: A crosssectional study. Ann Afr Med. 2015;14(1):25-31. https://doi. org/10.4103/1596-3519.148725

PMid:25567692

2. The FRESH Framework. Access to Health and Nutrition Services. Focusing Resources on Effective School Health (FRESH)-Health Related School Policies, Safe Water and Sanitation, and Skills Based Health Education; 2013. https://doi. org/10.4135/9781452276250.n224

3. Austin AM, Fawzi W, Hill AG. Anaemia among Egyptian children between 2000 and 2005: Trends and predictors. Matern Child Nutr. 2012;8(4):522-32. https://doi. org/10.1111/j.1740-8709.2011.00339.x PMid:21951327

4. Egypt Demographic and Health Survey. Nutrition of Children, Youth, and Women. Ch. 12. Cairo, Egypt: Egypt Demographic and Health Survey; 2014. Available from: https://www. dhsprogram.com/pubs/pdf/fr302/fr302.pdf. [Last accessed on 2019 Oct 10]

5. Abdel-Rasoul GM, El Bahnasy RE, El Shazly HM, Gabr HM, Abdel-Aaty NB. Epidemiology of iron-deficiency anemia among primary school children (6-11 years), Menoufia governorate, Egypt. Menoufia Med J. 2015;28:663-9. https:// doi.org/10.4103/1110-2098.165127

6. Tayel D, Ezzat S. Anemia and its associated factors among adolescents in Alexandria, Egypt. Int $\mathrm{J}$ Health Sci Res. 20155(10):260-71.

7. WHO, UNICEF. Focusing on Anemia: Towards an Integrated Approach for Effective Anemia Control. Geneva: World Health Organization; 2004.

8. Metwally AM, Saleh RM, El-Etreby LA, Salama SI, Aboulghate A, Amer HA, et al. Enhancing the value of women's reproductive rights through community based interventions in Upper Egypt governorates: A randomized interventional study. Int J Equity Health. 2019;18(1):146. https://doi.org/10.1186/ s12939-019-1042-y

PMid:31533741

9. Shiha G, Metwally AM, Soliman R, Elbasiony M, Mikhail NN, Easterbrook P. An educate, test, and treat programme to reduce hepatitis $\mathrm{C}$ in Egypt: Results from a communitybased demonstration project. Lancet Gastroenterol Hepatol. 2018;3(11):778-9. https://doi.org/10.1016/ s2468-1253(18)30139-0 PMid:30030068

10. Metwally AM, Saad A, Ibrahim NA, Emam HM, El-Etreby LA Monitoring progress of the role of integration of environmental health education with water and sanitation services in changing community behaviours. Int J Environ Health Res. 2007;17(1):6174. https://doi.org/10.1080/09603120600937856

\section{PMid:17365081}

11. Metwally AM, Ibrahim NA, Saad A, Abu El-Ela M. Improving the roles of rural women in health and environmental issues. Int J Environ Health Res. 2006;16(2):133-44. https://doi. org/10.1080/09603120500539208 


\section{PMid:16546806}

12. Kim-Gregory MT. HemoCue Hb201 Hemoglobin Procedure (LTR19555); 2008. Available from: https://www.massgeneral org/pathology/assets/pdf/hemocuehgbprocedureltr19555.pdf. [Last accessed on 2018 August 15].

13. Medonic M32 Analyzer. Available from: http://www.medonic.se. [Last accessed on 2018 July 22].

14. EPIC-Norfolk Food Frequency Questionnaire. Available from: http://www.srl.cam.ac.uk/epic/epicffq/ffq.pdf. [Last accessed on 2018 August 12].

15. Nelson M, Erens B, Bates B, Church S, Boshier L. 24-Hour Recall Instructions. Kings College London; 1994. Available from: http://dapa-toolkit.mrc.ac.uk/documents/en/24h/24hr instructions_lidns.pdf. [Last accessed on 2018 August 12].

16. Nutri Survey Program. Available from: http://www.nutrisurvey. de. [Last accessed on 2018 November 18].

17. Council for International Organizations of Medical Sciences (CIOMS), WHO. International Ethical Guidelines for Biomedical Research Involving Human Subjects; 2002. Available from: https://www.cioms.ch/revising-2002-cioms-ethical-guidelinesbiomedical-research-involving-human-subjects. [Last accessed on 2017 May 14].

18. Nabakwe EC, Lichtenbelt W, Ngare DK. Vitamin A deficiency and anemia in young children living in a malaria endemic district of western Kenya. East Afr Med J. 2005;82(6):300-6. https://doi. org/10.4314/eamj.v82i6.9301

PMid: 16175781

19. El Kishawi RR, Soo KL, Abed YA, Manan WA. Anemia among children aged 2-5 years in the Gaza strip-palestinian: A cross sectional study. BMC Public Health. 2015;15:319. https://doi. org/10.1186/s12889-015-1652-2

PMid:25879619

20. Hashizume M, Kunii O, Sasaki S, Shimoda T, Wakai $S$, Mazhitova Z, et al. Anemia and iron deficiency among schoolchildren in the Aral sea region, Kazakhstan. J Trop Pediatr. 2003;49(3):172-7. https://doi.org/10.1093/tropej/49.3.172 PMid:12848209

21. Rojhani A, Niewiadomska-Bugaj M. Nutrition education and anaemia outcome in inner city black children. J Fam Ecol Consum Sci. 2004;32:116-27. https://doi.org/10.4314/jfecs. v32i1.52860

22. Gitau GN, Kimiywe JO, Waudo JN, Mbithe D. Effects of nutrition education on nutrition knowledge and iron status in primary school pupils of Gatanga district, Muranga County, Kenya. Curr Res Nutr Food Sci J. 2013;1(2):115-23. https://doi.org/10.12944/ crnfsj.1.2.02

23. Grover K, Choudhary M. Effectiveness of long term community based nutrition intervention for prevention and management of anaemia among adolescent girls. Asian J Dairy Food Res. 2017;36(3):235-40. https://doi.org/10.18805/ajdfr.v36i03.8961

24. Shet AS, Zwarenstein M, Rao A. Effect of a community health worker-delivered parental education and counseling intervention on anemia cure rates in rural Indian children: A pragmatic cluster randomized clinical trial. JAMA Pediatr. 2019;173(9):826-34. https://doi.org/10.1001/jamapediatrics.2019.2087 PMid:31329246

25. Amani $R$, Soflaei M. Nutrition education alone improves dietary practices but not hematologic indices of adolescent girls in Iran. Food Nutr Bull. 2006 27(3):260-4. https://doi. org/10.1177/156482650602700309

26. Kumari J, Dubey RP. Impact of nutrition education on iron deficiency anaemia among college student of Banasthali University, Rajasthan. Food Sci Res J. 2016;7(1):74-9. https:// doi.org/10.15740/has/fsrj/7.1/74-79
27. Gitau GN, Kimiywe JO, Waudo JN. Quality nutrition education and its impact on haemoglobin levels of school pupils of Muranga County, Kenya. Int J Adv Nutr Health Sci. 2016;4(1):155-73. https://doi.org/10.23953/cloud.ijanhs.137

28. Ruzita A, Wan Azdie M, Ismail M. The effectiveness of nutrition education programme for primary school children. Malays $\mathrm{J}$ Nutr. 2007;13(1):45-54.

PMid:22692188

29. Otoo G, Adam Y. Effect of nutrition education with an emphasis on consumption of iron-rich foods on hemoglobin levels of pregnant women in Ghana. FASEB J. 2016;30(S1):410.2.

30. Abdel-Rasoul GM, Elgendyb FM, Elrazek ML. Iron deficiency anemia among preschool children (2-6 years) in a Slum area (Alexandria, Egypt): An intervention study. Menoufia Med J. 2017;30(1):213-20. https://doi.org/10.4103/1110-2098.211534

31. Singh M, Rajoura OP, Honnakamble RA. Anemia-related knowledge, attitude, and practices in adolescent schoolgirls of Delhi: A cross-sectional study. Int J Health Allied Sci. 2019;8(2):144-8.

32. Yusoff H, Daud WN, Ahmad Z. Effectiveness of nutrition education vs. non-nutrition education intervention in improving awareness pertaining iron deficiency among anemic adolescents. Iran J Public Health. 2013;42(5):467-71. PMid:23802103

33. Salah El-Din EM, Elabd MA, Nassar MS, Metwally AM, Abdellatif GA, Rabah TM, et al. The interaction of social, physical and nutritive factors in triggering early developmental language delay in a sample of Egyptian children. Open Access Maced J Med Sci. 2019;7(17):2767-74. https://doi.org/10.3889/ oamjms.2019.642

PMid:31844434

34. El-Din EM, Rabah TM, Metwally AM, Nassar MS, Elabd MA, Shaalan $A$, et al. Potential risk factors of developmental cognitive delay in the first two years of life. Open Access Maced J Med Sci. 2019;7(12):2024-30. https://doi.org/10.3889/oamjms.2019.566 PMid:31406549

35. Kandeel WA, Rabah TM, Zeid DA, El-Din EM, Metwally AM, Shaalan A, et al. Determinants of exclusive breastfeeding in a sample of Egyptian infants. Open Access Maced J Med Sci. 2018;6(10):1818-23. https://doi.org/10.3889/oamjms.2018.359 PMid:30455755

36. Metwally AM, Salah El-Din EM, Shehata MA, Shaalan A, El Etreby LA, Kandeel WA, et al. Early life predictors of socioemotional development in a sample of Egyptian infants. PLoS One. 2016;11(7):e0158086. https://doi.org/10.1371/journal. pone.0158086 PMid:27379907

37. Monir ZA, Khalifa AG, Metwally AM, Hamid NA, Hussien HA Salah EM. The impact of social status and school meal on psychosocial behavior in governmental primary school children in Egypt. J Appl Sci Res. 2013;9(6):3556-5.

38. Salah EM, Khalifa AG, Metwally AM, Hamid NA, Hussien HA Moneer ZM. The impact of school snacks on cognitive function of primary school children in Egypt. J Appl Sci Res. 2012;8(12):5639-50.

39. Kaur M, Bassi R, Sharma S. Impact of nutrition education in reducing iron deficiency anaemia in adolescent girls. Indian $\mathrm{J}$ Fundam Appl Life Sci. 2011;1:222-8.

40. Mustafa A, Maulidiana AR. The effectiveness of nutrition education about local specific food-based balanced nutrition recommendation on dietary intake level and anemia status in female adolescents at the hidayatullah arrohmah Islamic boarding school malang. In: The First International Conference on Health Profession. Dubai: KnE Life Sciences; 2019. p. 23-31. https://doi.org/10.18502/kls.v4i15.5730 